\title{
Perancangan Dan Implementasi Sistem Informasi Koperasi Pegawai Negeri (KPN) Pada Koperasi "Kapur Warna” Kecamatan Naggalo Kota Padang
}

\author{
Meri Azmi \\ Jurusan Teknologi Informasi, Politeknik Negeri Padang \\ meriazmi@gmail.com
}

\begin{abstract}
ABSTRAK
Koperasi Pegawai Negeri (KPN) Kapur Warna Kecamatan Nanggalo Kota Padang merupakan salah satu koperasi yang bergerak dalam usaha simpan pinjam. Dalam pengelolaan data baik itu data simpanan, data pinjaman, data angsuran anggota serta perhitungan Sisa Hasil Usaha (SHU) masih penggunakan perhitungan dan pengolahan data secara manual menggunakan aplikasi Microsoft Excel. Kemampuan dari aplikasi ini masih terbatas dalam hal pengelolaan dan manajemen data koperasi sehingga KPN- Kapur Warna membutuhkan suatu sistem informasi yang mampu mengolah data secara cepat, tepat dan akurat. Sistem Informasi Koperasi Simpan Pinjam dirancang dan diimplementasikan pada koperasi ini untuk memenuhi kebutuhan akan pengolahan data tersebut. Kemudahan dalam pengelolaan data anggota koperasi, manajemen data simpanan dan pinjaman serta kemudahan dalam pembuatan laporan. Sistem ini dirancang berbasis web agar nantinya sistem ini bisa diintegrasikan secara online sehingga setiap anggota koperasi bisa melihat secara berkala data atas simpanan, pinjaman dan perkembangan usaha koperasi ini.
\end{abstract}

Kata Kunci : Koperasi, Sistem Informasi, MySQL, PHP

\section{PENDAHULUAN}

Dalam dunia usaha dan dunia industri saat ini, kebutuhan akan suatu sistem dalam pengolahan data begitu tinggi. Agar mencapai efektivitas dan efisiensi dalam mencapai target kerja dan target usaha, baik untuk bagian penerimaan karyawan, penjualan, manajemen karyawan sampai dengan laporan keuangan. Terutama untuk suatu badan usaha tertentu.

Salah satu badan usaha tersebut adalah koperasi. Koperasi adalah badan usaha yang beraggotakan orang atau badan hukum koperasi denganberlandaskan kegiatannya sebagai gerakan ekonomi rakyat yang berdasarkan atas asaskekeluargaan. Pengertian tersebut sesuai dengan UU Koperasi No. 25 tahun 1992 Bab I.

Koperasi "Kapur Warna”adalah salah satu Koperasi Pegawai Negeri yang terletak di Kecamatan Nanggalo Kota Padang, Sumatera Barat. Koperasi ini merupakan salah satu koperasi yang mempunyai usaha simpanpinjam dan usaha dagang. Sejak pertama kali didirikan koperasi ini telah memfokuskan dalambidang usaha simpan pinjam, dimana hasil dari simpanan para anggota koperasi selain dipinjamkankembali juga digunakan untuk usaha dagang atau disebut "usaha toko".

Pelayanan yang sekarang berjalan masih dilakukan dengan cara manual, hal tersebut dapat dilihat dari proses transaksi simpan, pinjam, pembayaran angsuran, dan pengolahan anggota. Dimana dengan proses yang manual sering terjadi kesalahan pencatatan, arsip yang sulit dicari, danlain sebagainya.

Untuk meningkatkan pelayanan anggota, koperasi berusaha memudahkan dengan caramempersiapkan teknologi informasi khususnya sistem informasi akuntansi. Sistem ini bertujuan untuk memudahkan koperasi dalam mengolah data keuangan..

Berdasarkan hal tersebut diatas, maka diperolah suatu rumusan masalah yaitu bagaimana merancang dan me-implementasikan Sistem Informasi Koperasi pada Koperasi Pegawai Negeri (KPN) "Kapur Warna" menggunakan bahasa pemograman PHP dan MYSQL.

Dengan rumusan masalah tersebut, maka akan dibuat sistem informasi koperasi dengan batasan sebagai berikut:

a. Sistem informasi ini dapat mengelola data anggota.

b. Sistem informasi ini dapat mengelola data simpanan, pinjaman dan angsuran anggota.

c. Sistem informasi ini dapat mengelola Sisa Hasil Usaha (SHU) dalam Usaha Simpan Pinjam (USP) pada Rapat Anggota Tahunan ( RAT). 


\section{Tinjauan Pustaka}

Sistem informasi adalah serangkaian proses dalam mengolah data data dan fakta sehingga dapat menghasilkan informasi yang berkualitas.

Menurut Bonnie dan Marion [1] "Sistem Informasi adalah serangkaian komponen komponen berupa manusia, prosedur, data, dan teknologi (seperti computer) yang digunakan untuk melakukan sebuah proses untuk menghasilkan informasi yang bernilai untuk pengambilan keputusan"

Menurut Sistem infromasi terdiri dari komponenkomponen yang disebut blok bangunan (building block), yang terdiri dari komponen input, komponen model, komponen output, komponen teknologi, komponen hardware, komponen software, komponen basisdata, dan komponen kontrol. Seperti terlihat pada Gambar 1.

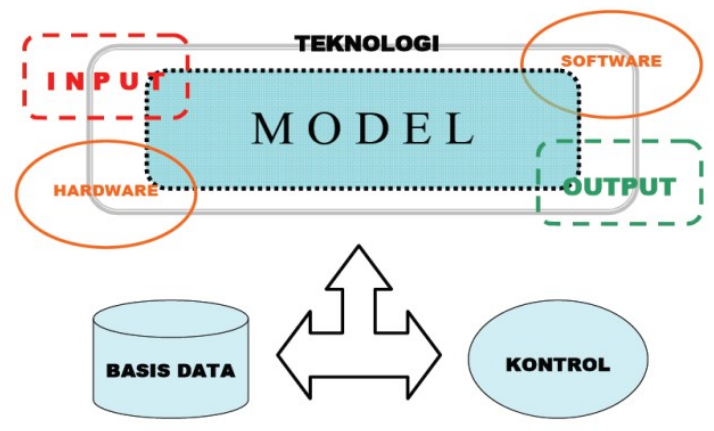

Gambar 1. Interaksi Sistem Informasi

1. Komponen Input

Input mewakili data yang masuk ke dalam sistem informasi. Input disini termasuk metode dan media untuk menamngkap data yang akan dimasukkan, yang dapat berupa dokumendokumen dasar.

2. Komponen Model

Komponen ini terdiri dari kombinasi prosedur, logika, dan model matematik yang akan memanipulasi data input dan data tersimpan di basisdata dengan cara yang sudah ditentukan untuk menghasilkan keluaran yang diinginkan.

3. Komponen Output

Hasil dari sistem informasi adalah keluaran yang merupakan informasi yang berkualitas dan dokumentasi yang berguna untuk semua pemakai system.

4. Komponen Teknologi

Teknologi merupakan tool box dalam sistem informasi. Teknologi digunakan untuk menerima input, menjalankan model, menyimpan dan mengakses data, menghasilkan dan mengirimkan keluaran, dan membantu pengendalian dari sistem secara keseluruhan.

5. Komponen Hardware

Hardware berperan penting sebagai suatu media penyimpanan vital bagi sistem informasi. Yang berfungsi sebagai tempat untuk menampung database atau lebih mudah dikatakan sebagai sumber data dan informasi untuk memperlancar dan mempermudah kerja dari sistem informasi.

6. Komponen Software

Software berfungsi tempat untuk mengolah, menghitung dan memanipulasi data yang diambil dari hardware untuk menciptakan suatu informasi.

7. Komponen Basisdata

Basisdata (database) merupakan kumpulan data yang saling berkaitan dan berhubungan satu dengan yang lain, tersimpan di perangkat keras komputer dan menggunakan perangkat lunak untuk memanipulasinya. Data perlu disimpan dalam basisdata untuk keperluan penyediaan informasi lebih lanjut. Data di dalam basis dara perlu diorganisasikan sedemikian rupa supaya informasi yang dihasilkan berkualitas. Organisasi basisdata yang baik juga berguna untuk efisiensi kapasitas penyimpanannya. Basisdata diakses atau dimanipulasi menggunakan perangkat lunak paket yang disebut DBMS (Database Management System).

8. Komponen Kontrol

Banyak hal yang dapat merusak sistem informasi, seperti bencana alam, api, temperature, air, debu, kecurangan-kecurangan, kegagalan-kegagalan sistem itu sendiri, ketidakefisienan, sabotase dan lain sebagainya. Beberapa pengendalian perlu dirancang dan diterapkan untuk meyakinkan bahwa hal-hal yang dapat merusak sistem dapat dicegah ataupun bila terlanjur terjadi kesalahnkesalahan dapat langsung cepat diatasi.

Basisdata (Database)

Basisdata merupakan bagian penting dalam sebuah sistem informasi. Basisdata dalam sistem informasi dapat mempunyai peranan sebagai berikut

1. Basisdata sebagai komponen penyusun sistem informasi

2. Basisdata sebagai infrastruktur sistem informasi

3. Basisdata sebagai sumber informasi bagi sistem informasi

4. Basisdata sebagai sarana mencapai efisiensi sistem informasi

5. Basisdata sebagai sarana mencapai efektifitas sistem informasi

Basisdata (database) merupakan kumpulan data (elemeter) yang secara logik berkaitan dalam mempresentasikan fenomena/fakta secara terstruktur dalam domain tertentu untuk mendukung aplikasi pada sistem tertentu. Basisdata ini merupakan komponen utama sistem informasi karena semua informasi untuk pengambilan keputusan berasal dari data di basisdata. Pengelolaan basisdata yang buruk dapat mengakibatkan ketidaktersediaan data penting yang digunakan untuk menghasilkan informasi yang diperlukan dalan pengambilan keputusan [8]. 
Antarmuka (interface) antara pengguna basisdata dapat digambarkan sebagaimana ditunjukkan oleh Gambar 2.



Gambar 2. Antarmuka antara Pengguna dan Basisdata [2]

Gambar 2 diatas menjelaskan tentang kebutuhan data dari para pengguna memerlukan sistem pengelolaan basisdata (Database Management System/DBMS) untuk mendeskripsikan kebutuhan tersebut, serta kondisi kewenangan dan keamanan data. Data dalam fisik media penyimpanan diketahui berdasarkan model eksternalnya. Berdasarkan deskripsi fisik tersebut diketahui model internal dari metode akses yang digunakan. DBMS mnentukan model internal, yaitu metode akses yang akan diimplementasikan secara berbeda-beda. Metode akses dalam model internal bersama-sama OS mengakses record dari fisik media penyimpanan sekunder.

\section{Metode Penelitian}

Dalam mendapatkan data dan keterangan yang akurat yang sesuai dengan masalah yang sedang dihadapi, maka metodologi yang digunakan dalam penulisan sebagai berikut :

A. Penelitian Lapangan

a. Secara langsung

Penelitian lapangan dilakukan langsung dengan mencari dan meminta data yang bersifat manual yang dibutuhkan dalam merancang sistem langsung ke KPN "Kapur Warna”

b. Secara Wawancara

Melakukan wawancara dengan pengurus koperasi untuk mengetahui lebih jelas seperti apa input dan output sistem yang dibutuhkan.

B. Studi Kepustakaan

Studi Kepustakaan ini merupakan teknik pengumpulan data dengan melakukan penelitian melalui perpustakaan dan mempelajari buku-buku yang berhubungan dengan penelitian yang dijadikan landasan teori.

C. Analisis

Analisis merupakan penguraian dari sistem informasi yang utuh kedalam bagian-bagian komponennya dengan maksud untuk mengidentifikasi dan mengevaluasi permasalahan yang terjadi sehingga dapat diusulkan perbaikannya dan perancangan sistemnya dari sistem manual yang sedang berjalan.

D. Perancangan

Meliputi perancangan konteks diagram, basis data dan sistem yang akan dibuat.

E. Implementasi

Merupakan penerapan dari hasil rancangan sistem yang sudah di ujicoba dan layak untuk digunakan dilingkungan KPN "Kapur Warna". Dimana sistem ini langsung akan disimpan dalam server Lokal KPN "Kapur Warna".

F. Uji Coba dan Evaluasi

Uji coba sangat dibutuhkan sebelum sistem diimplementasikan dalam lingkungan KPN "Kapur Warna" dimana disini akan di analisa dan di evaluasi kekurangan-kekurangan sistem yang sudah dirancang agar sesuai dengan input,output dan proses data yang dibutuhkan.

\section{Pembahasan}

Perancangan Sistem

Sistem yang akan dirancang dan diimplementasikan diharapkan mampu untuk melakukan :

A. Transaksi Data (Proses Data Sistem)

Adapun proses transakasi data yang terjadi dalam sistem ini adalah :

a. Proses penyimpanan dana dari masingmasing anggota koperasi

b. Proses penarikan dan peminjaman dana dari mashng-masing anggota

c. Penghitungan Sisa Hasil Usaha yang didapat setelah Rapat Anggota Tahunan Koperasi

d. Proses pembayaran pinjaman dana

e. Manajemen anggota koperasi

B. Informasi Data Masukan (Input Data Sistem)

Adapun data-data yang dibutuhkan untuk sistem ini adalah :

a. Data anggota koperasi

b. Data simpanan anggota

c. Informasi Keluaran (Output Data Sistem)

Adapun output yang ingin dihasilkan adalah :

a. Laporan anggota koperasi

b. Laporan aliran dana masuk dan keluar

c. Informasi sisa hasil usaha

d. Laporan Keuangan

\section{Diagram Context}

Merupakan level tertinggi dari DFD, yang menggambarkan seluruh input ke atau output dari 
sistem dan memberikan gambaran tentang keseluruhan sistem.

Diagram konteks informasi keoperasi terdiri dari emapat entitas yaitu anggota, sekretaris, bendahara dan ketu koperasi, dimana setiap entititas mempunyai hak input dan input dari sistem yang dapat dilihat seperti yang digambarkan pada gambar 3 sebagai berikut :

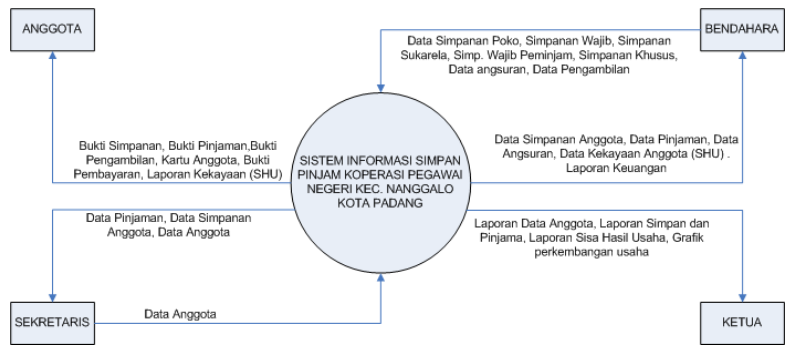

Gambar 3. Diagram Konteks SI Koperasi Simpan Pinjam

Rancangan Basis Data

Rancangan Basis Data diperlukan untuk membuat aplikasi Sistem Pendukung Keputusan nantinya. Dalam penelitian ini, desain databasenya adalah sebagai berikut

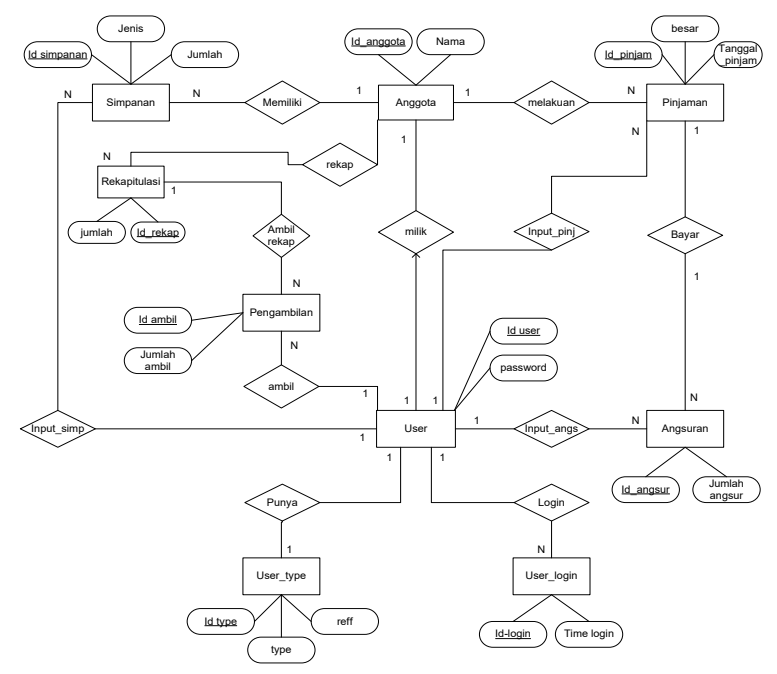

Gambar 4. Rancangan ERD SI Koperasi simpan pinjam

Pada Gambar 4 tampak relasi antar tabel yaitu sebgai berikut :

1. Setiap anggota memiliki banyak simpanan dan setiap simpanan hanya dimiliki oleh satu anggota sehingga pada atribut simpanan diatmbahkan ID_anggota.

2. Setiap anggota boleh melakukan banyak pinjaman dan satu pinjaman juga dimiliki oleh 1 orang anggota sehingga pada atribut pinjaman ditambahkan id_anggota.

3. Satu pinjaman bisa diangsur oleh banyak angsuran, namun satu angsuran hanya untuk satu pinjaman sehingga pada angsuran ditambahkan atribut id_pinjam.Satu simpanan bisa diambil oleh banyak pengambilan, namun satu pengambilan hanya untuk satu pinjaman

4. Semua transaksi simpan, pinjma, angsuran dan pengambilan dilakukan oleh user.

5. Satu user juga punya satu type yser dimana satu tipe user bisa mengakses banyak modul sesuai dengan hak akses usernya.

Perancangan Antarmuka

Setelah dilakukan perancangan database maka tahap selanjutnya adalah perancangan tampilan aplikasi. Tampilan ini diawal dengan perancangan struktur menu akses. Adapun struktur menu SI Koperasi Simpan Pinjam terlihat pada gambar 5 berikut

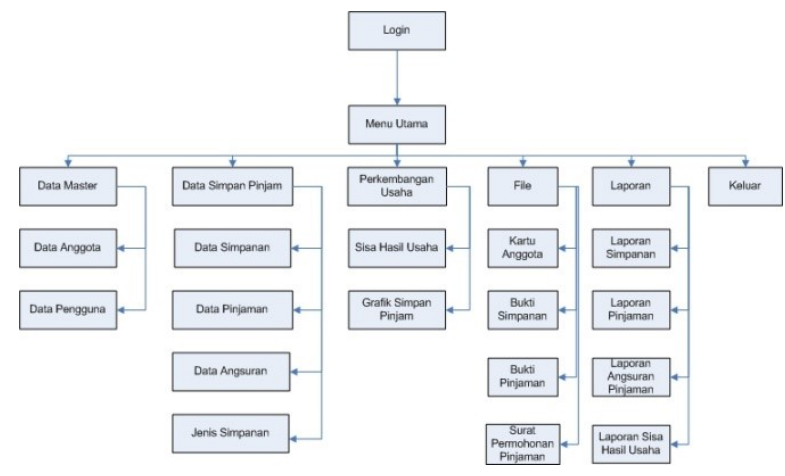

Gambar 5 Struktur menu SI Koperasi Simpan Pinjam

\section{Hasil dan Pembahasan}

Untuk membuka sistem ini dengan mengetikkan alamat aplikasi yaitu localhost/kapurwarna, maka halaman awal yang muncul adalah halaman loginuntuk masuk kedalam sistem. Setalah login dengan menggunakan username dan password maka akan muncul halaman beranda sebagai halaman awal setalah sukses login. Berikut halaman beranda sistem seperti yang terlihat pada Gambar 6. 


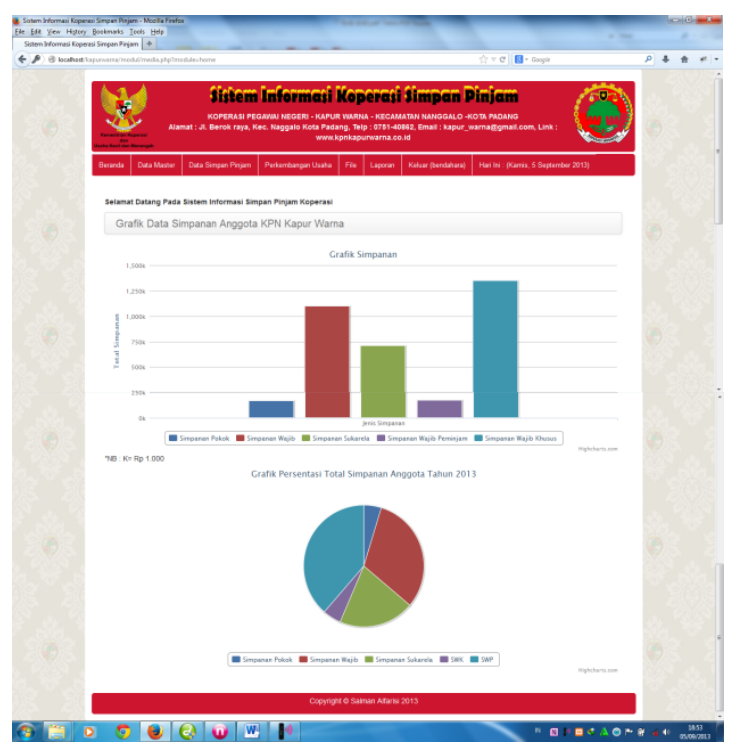

Gambar 6. Halaman Beranda Sistem

Proses Penyimpanan

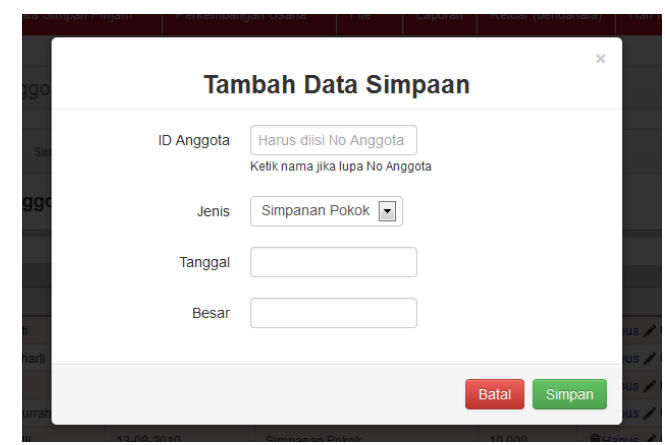

Gambar 7. Form tambah simpanan

Pada gambar 7 diatas ada listbox jenis simpanan yang akan dipilih sesuai dengan jenis simpanan yang akan disimpan. Setalah form ini diisi dan dipilih simpan maka akan kembali pada tabel data simpanan.

\section{Proses Peminjaman}

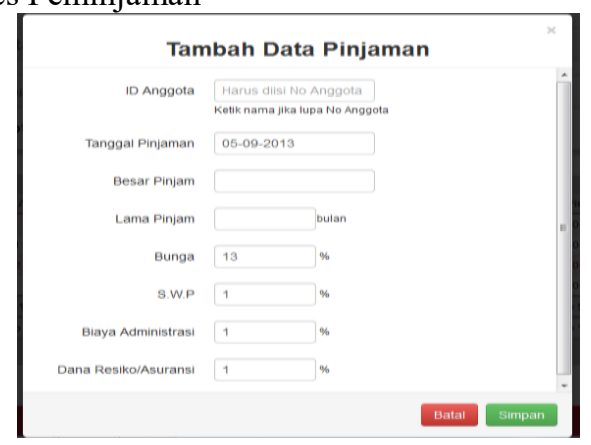

Gambar 8. Form tambah data pinjaman

Form ini berisi data pinjaman dan angsuran yang telah dilakukan peminjam atas pinjamannnya, adapun data angsuran tersebut adalah seperti gambar berikut:

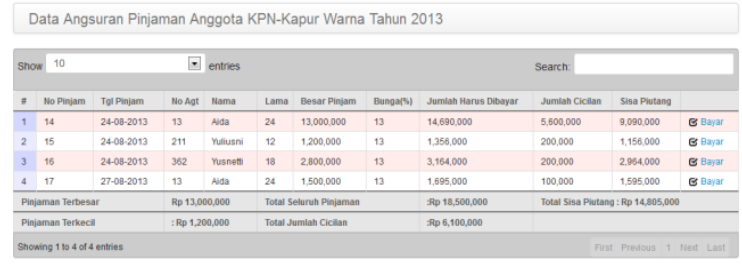

Gambar 9. Form data angsuran

Pada data angsuran diatas disediakan link bayar untuk melakukan pembayaran angsuran atas pinjaman anggota. Jika link bayar tersebut di klik makan akan muncul form data pembayaran angsuran seperti gambar 10 .

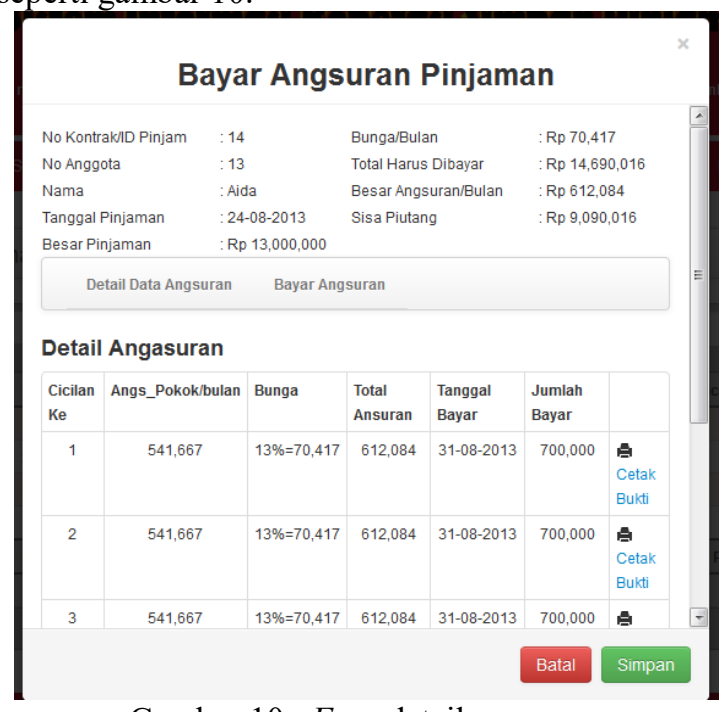

Gambar 10. Formdetail angsuran

Pada form diatas akan muncul data detail pinjaman dan angsuran. Form diatas menyediakan 2 tab yaitu tab detail data angsuran untuk melihat data angsuran dan tab bayar angsuran untuk melakukan pembayaran angsuran. Jika tab bayar angsuran diklik maka akan muncul form inputnya seperti gambar 11.

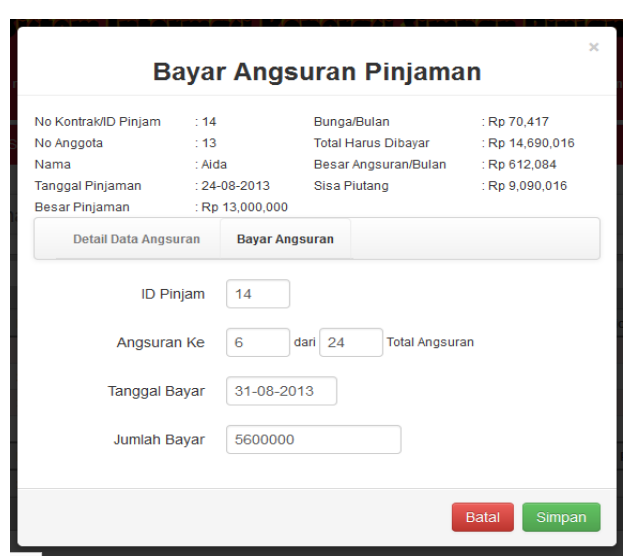

Gambar 11. Form: bayar angsuran 
Laporan

Laporan data simpanan bisa diakses pada menu laporan dan tab laporan simpanan seperti gambar berikut :

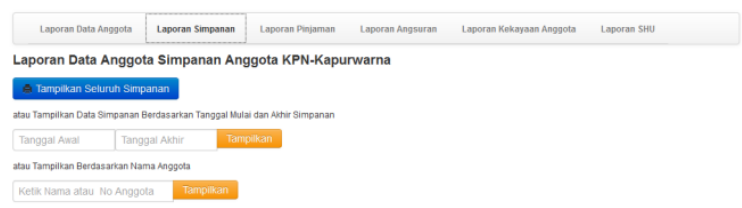

Gambar 11. Menu cetak laporan simpanan

Pada tampilan diatas laporan data simpanan anggota bisa dilihat secara keseluruhan maupun per tanggal. Untuk menampilkan laporan data simpanan anggota dengan cara menekan tombol tampilkan dan laporannya seperti gambar 12

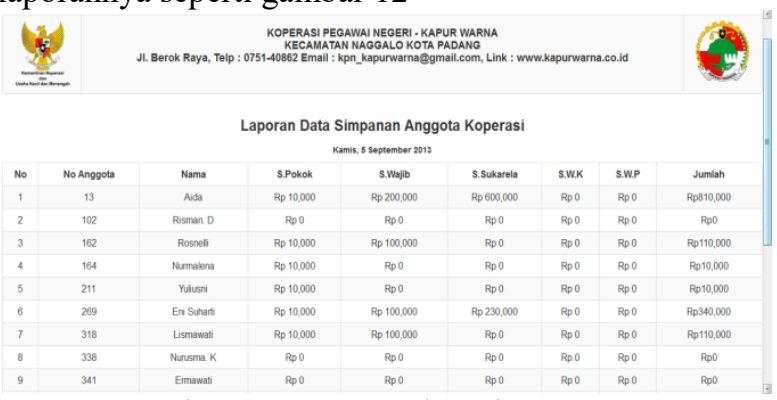

Gambar 12. Laporan data simpanan

Sama halnya dengan laporan data simpanan, laporan data pinjaman juga bisa diakses pada menu laporan dan tab laporan pinjaman. Hasil dari laporan data pinjaman adalah seperti gambar 13

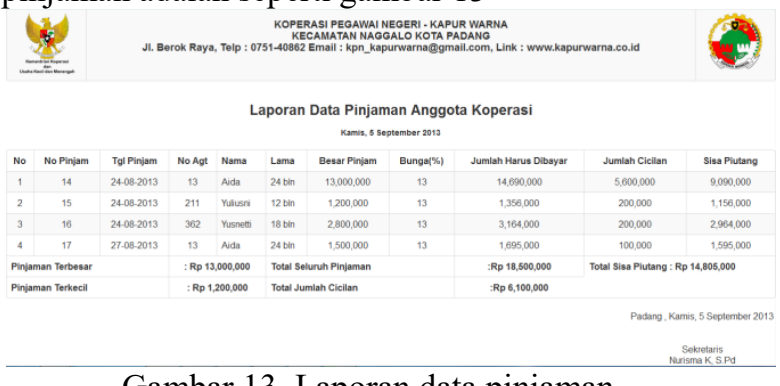

Gambar 13. Laporan data pinjaman

Laporan sisa hasil usaha berisi rincian sisa hasil usaha yang diperoleh anggota koperasi berdasarkan simpanan dan transaksi pinjaman yang dilakukan, berikut tampilan laporan SHU yang diterima anggota

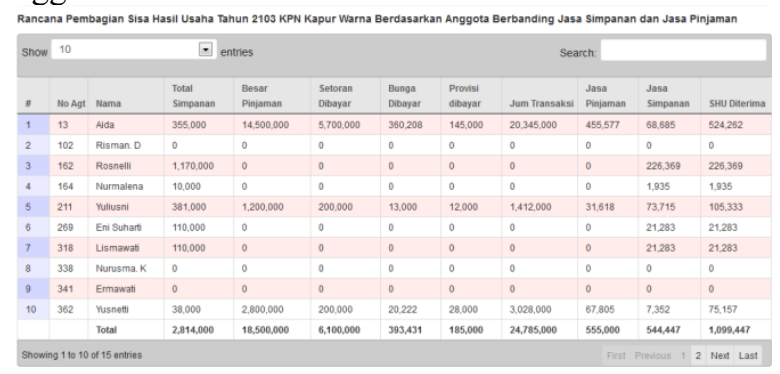

Gambar 14. Laporan sisa hasil usaha

\section{KESIMPULAN}

Berdasarkan uraian dari perancangan dan implementasi sistem informasi koperasi simpan pinjam beserta tujuannya dan berdasarkan analisa dari data yang ada maka dapat penulis tarik kesimpulan sebagai berikut :

1. Sistem yang dibangun dapat membantu meningkatkan efisiensi dan efektifitas serta ketelitian perhitungan simpan pinjam ole pengurus koperasi dalam mengelola data simpanan dan data pinjaman anggota koperasi.

2. Sistem menghasilkan pencarian data yang cepat terhadap suatu kata kunci yang ingin ditampilkan.

3. Perhitungan Sisa Hasil Usaha bisa dilihat setiap waktu tanpa harus melakukan perhitungan manual karena pengolahan perhitungan SHU disesuaikan dengan ketentuan perhitungan SHU KPN-Kapur Warna

4. Berdasarkan batasan masalah, sistem yang dirancang menghasilkan laporan keungan berupa laporan kekayaan anggota, laporan simpanan dan laporan pinjaman anggota koperasi serta laporan sisa hasil usaha.

5. Dengan adanya grafik simpanan akan membantu pengurus koperasi dan anggota dalam menentukan kebijakan-kebijakan koperasi kedepannya.

\section{SARAN}

Berdasarkan kesimpulan diatas dan dari hasil sistem yang telah dibangun dapat diberikan saran sebagai berikut :

1. Dengan adanya sistem ini diharapkan adanya pengembangan yang berkelanjutan atas kekurangan-kekurang dari sistem ini baik bagi pembaca maupun bagi tempat usaha yang menjadi tempat implementasi sistem ini karena sistem ini dibangun masih terdapat kekurangan-kekurangan.

2. Diharapkan sistem ini dipergunakan terus sehingga proses simpan pinjam di KPN- Kapur Warna bisa lebih efektif dan efisien.

3. Pada sistem yang dibangun, alokasi persentasi SHU Koperasi masih bersifat konstan. Diharapkan bagi pembaca yang akan mengembangkan sistem agar persentasi alokasi SHU ini bisa nantinya bersifat fleksibel.

4. Adanya standar baku terhadap ketentuan pendanaan dan pengalokasian dana koperasi serta ketentuan dalam simpan dan pinjam agar nantinya sistem yang dibangun berpedoman pada standar yang baku tersebut dan tidak terjadi perombakan sistem jika standar koperasi belum baku. 


\section{REFERENSI}

[1] Soeherman, Bonnie dan Marion Pinontoan, Designing Information System". Jakarta : PT. Elex Media Komputindo, 2008.

[2] Sutanta, Edhy, "Basis Data dalam Tinjauan Konseptual'. Yogyakarta : Penerbit Andi, 2011.

[3] Ferdinand Magaline dan Billy N Mahamudu (2009). "Sistem Informasi". http://apr11si.comuf.com/SI.pdf.

[4] Nugroho, Adi. “Konsep Pengembangan Sistem Basis Data". Bandung : Informatika Bandung. 2004.

[5] Haritini. “Analisis Dengan Diagram Keterhubungan Entitas(2010). http://unsri.ac.id/fasilkom/old_version/dosen/hart ini//materi/IX_ERD.pdf

[6] Yatini B, IndraFlowchart, "Algoritma dan Pemograman". Yogyakarta : Graha Ilmu, 2010.

[7] Hariyanto, Bambang. "Sistem Manajemen Basis Data, Pemodelan, Perancangan dan Terapan. Bandung" : Informatika, 2004.
[8] Waljiyanto. "Sistem Basis Data dan Analisis Pemodelan”. Yogyakarta: Graha Ilmu, 2003.

[9] Ladjamudin, Al-Bahra. "Analisis dan Desain Sistem Informasi”. Yogyakarta. Graha Ilmu, 2005.

[10] LAPENKOP Nasional.”Lebih Mengenal Koperasi”. Bandung. Tim LAPENKOP Nasional, 2004.

[11] LAPENKOP Nasional. "SHU Anggota Koperasi”. Bandung. Tim LAPENKOP Nasional, 2004.

[12] Pengurus KPN-Kapur Warna. Laporan Pertanggung Jawaban Pengurus dan Pengawas KPN Kapur Warna Tahun Buku 201"2. Padang : Pengurus KPN-Kapurwarn, 2012.

[13] Achmad, Rasyid, Hisbullah, Jerry. "Laporan Auditor Independen KPN- Kapur Warna per 31 Desember 2012. Jakarta. Kantor Akuntan Publik, 2012. 